\title{
How Bulgaria Can Contribute to Energetic Refurbishment of Real Estate in Germany
}

\author{
Ulrich Bodmer ${ }^{1 *}$, and Alois Heissenhuber ${ }^{2}$ \\ ${ }^{1}$ University of Applied Sciences Weihenstephan-Triesdorf, Freising, Germany \\ ${ }^{2}$ Technical University of Munich, Freising, Germany
}

\begin{abstract}
On 28th September 2010, the government of the Federal Republic of Germany set a political goal to achieve a "nearly climate-neutral building stock by 2050 ". Due to the long period from now up to 2050, an intermediate goal was set in 2019: Emission of climate-damaging gases in Germany must decrease by $55 \%$ by 2030 compared to 1990 . Up to now, however, Germany has only marginally come closer to either of these goals. According to the Federal Environment Agency, emissions of $\mathrm{CO} 2$ equivalents from the building sector in Germany in 2011 amounted to 128 megatons. In 2020 the emissions summed up to 120 megatons. Thus, the target set for 2050 cannot be achieved with the current refurbishment rate, especially not if the climate protection targets are now even tightened up by politicians and are now to be achieved by 2045 instead of 2050. But plants from Bulgaria and other Middle and Eastern European countries may play a decisive role to speed up the energetic refurbishment of buildings. Why and which plants may make significant contributions to the energy-efficient renovation of buildings in Germany is presented in this article.
\end{abstract}

\section{Introduction}

In September 2010 the government of the Federal Republic of Germany set a political goal: Germany has to be carbon neutral by 2050 [1]. Due to the long period up to 2050, an intermediate goal was set in 2019 [2]: Emission of climate-damaging gases in Germany must decrease by $55 \%$ by 2030 compared to 1990 . Up to now, however, Germany has only marginally come closer to this goal.

On 29th April 2021 the Federal Constutional Court of Germany, however, pronounced a judgement that the government of the Federal Republic of Germany has to operationalize the goals for the reduction of carbon dioxide emission after 2030 more precise.

Now the various democratic parties in Germany are calling for the court's verdict to be implemented quickly. Now carbon neutrality even has to be achieved by 2045 . This goal, however, requires a paradigm shift in many areas, a realignment of the economy: In industrial production, transport sector, energy sector, agriculture, etc.

This, however, won't be an easy job.

As an example, let's have a closer look upon the carbon dioxide emissions in the real estate sector and the agricultural sector. And let's analyze, how both sectors might use

\footnotetext{
*Corresponding author: ulrich.bodmer@hswt.de
} 
synergetic effects to reduce carbon dioxide emissions in total - and how Bulgaria might play a decisive role to help Germany to reduce its carbon dioxide emissions in the real estate sector.

\subsection{Problems}

\subsubsection{Real estate sector in Germany}

According to the Federal Environment Agency, emissions of $\mathrm{CO} 2$ equivalents from the building sector in Germany in 2011 amounted to 128 megatons. In 2020 the emissions still summed up to 120 megatons [3]. Thus, with the current rate of refurbishment neither the target set for 2045 nor the previous target set for 2050 will be achieved.

In the end, this would lead to significant increases in heating costs, especially for tenants as they have no chance to install better insulation and/or more efficient heating systems themselves. In order to encourage landlords to undertake energy-efficient renovation of the buildings, they will have to cover part of the tenants' rising heating costs in the future. This should be incentive enough for them to speed up the refurbishment rate of buildings in the future. There are manyfold possible measures to reduce $\mathrm{CO} 2$ emissions in the building sector:

- use of renewable energies for heating,

- replacement of old heating systems with more efficient ones

- use of building materials that are $\mathrm{CO}_{2}$-neutral both in the production of the rawmaterial and the dismantling.

New buildings should only replace existing buildings in exceptional cases and have to prove this necessity by means of a life cycle assessment [4].

Instead, it is necessary to better insulate the existing buildings. Only if the current high consumption of fossil material for heating in winter and cooling in summer will drastically be reduced by means of insulation, renewable energies will be able to meet the remaining demand for energy meant for heating etc. in a meaningful way.

Better insulation of existing houses along with a usage of $\mathrm{CO} 2$-neutral insulation-material is necessary.

\subsubsection{Real estate sector in Bulgaria}

Since September 2020 a DBU (Deutsche Bundesstiftung Umwelt) project is running in Nessebar to energetically refurbish the historical buildings with Typha boards [5].

\subsubsection{Agricultural Sector}

The German Umweltbundesamt [6] noted that about $62 \%$ of all methane $(\mathrm{CH} 4)$ emissions and $79 \%$ of nitrous oxide (N2O) emissions in Germany are caused by agriculture. Both gases tremendously contribute to the global warming effect. In 2018, German agriculture was responsible for a total of 63,6 million tonnes of carbon dioxide $(\mathrm{CO} 2)$ equivalents. That is $7.4 \%$ of the total "greenhouse gas" emissions for the year in Germany. After the energyrelated emissions from stationary and mobile combustion $(82.9 \%)$ and the process-related emissions from industry $(7.5 \%)$, emissions from agriculture make up a substantial proportion of greenhouse gas emissions in Germany.

Also, $\mathrm{CO} 2$ emissions from land-use changes (e.g., drainage of moors in order to use these areas as farmland) have to be taken into consideration.

The IPCC identifies agriculture, forestry and other land use (AFOLU) as a significant net source of GHG emissions, contributing to about $23 \%$ of anthropogenic emissions of carbon 
dioxide (CO2), methane (CH4) and nitrous oxide (N2O) combined as $\mathrm{CO} 2$ equivalents in 2007-2016 [7].

In order to meet the climate goals, set for 2045/50, emissions of CO2eq in agriculture need to be reduced significantly. One approach, among others, would be to stop the degradation of organic biomass in soils. Moors should be climate neutral. They even could be sinks for $\mathrm{CO} 2$. In Germany, however, they have been drained to a large extent since the middle of the 18th century and have been used for agriculture ever since. The result is that around 46 million tons of CO2eq/a are released in Germany every year from these degraded peatlands [8]. Peatland used for agriculture comprises 5\% of the total farmland in Germany. But this comparatively small area emits about $40 \%$ of the GHG emissions of Germany's agriculture and about 5\% of the total GHG emissions in Germany [8].

Renaturation of these former - now drained and degraded - peatlands would be ideal for climate protection. However, this would mean that farmers and residents would have to be expropriated and compensated for round about 1,4 to 1,8 Mio. ha [9] of former moorland in Germany - not only for agricultural use that would no longer be possible, but also for buildings that are no longer usable due to high water level, necessary to achieve a renaturation of peatland etc.

Instead of the complete renaturation of the former peatlands, the use of these areas for the cultivation of paludiculture is being discussed. This is intended to put a stop to the further breakdown of the peat body. The farmers would grow, harvest and sell paludiculture (Typha, reed, phalaris etc.). The material use of these harvested goods would be possible in order to capture carbon dioxide for a long time. For material use (as building materials) there are pilot applications with Typha that could demonstrate an excellent contribution to the energetic renovation of buildings by using these renewable resources - compare Krus et al. [10].

Additionally, these paludiculture plants do not only grow on peatland, but also along eutrophic water bodies, thus also helping to capture carbon dioxide and also helping to clean these water bodies.

\subsection{Objectives}

The real estate sector urgently needs a refurbishment of the insulation of the building. Additionally, the agricultural sector emits to much CO2eq, especially when agricultural production takes place on drained and degrades former peatland.

These two problems might be solved in common by switching from an economy based on (burning) fossile fuels to an economy based on using renewable resources primarily for insulation (bioeconomy) in order to save fossile resources.

Therefore, the objective of this article is to present proposals for the climate-neutral refurbishment of real estate (compare [11]) based on construction material made of the paludiculture plant Typha, to demonstrate the economic advantages and to give suggestions for the further development of building materials. This should also open up new perspectives for the sustainable production of renewable resources in Bulgaria by planting, harvesting and processing of these resources to produce building material, leading to a sustainable way of generating income.

\section{Overview of the current situation}

The residential building sector is one of the largest sources of $\mathrm{CO} 2$ emissions in Germany. With around 18.8 million residential buildings and 2.7 million non-residential buildings, the building sector in Germany is responsible for about 36 percent of the total final energy consumption in Germany. Around two thirds of this is caused by residential buildings, with 
the largest share being required for the generation of space heating and hot water (compare figure 1).

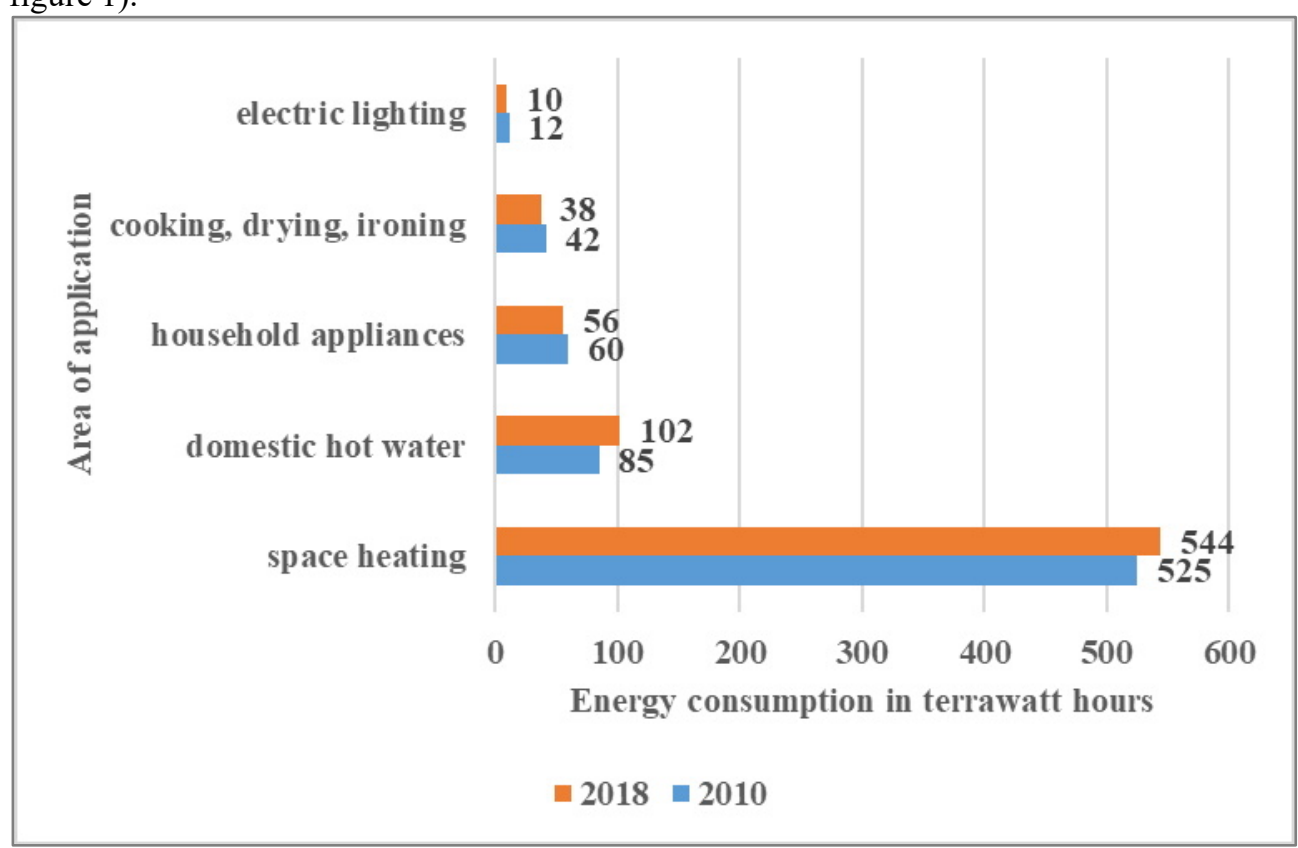

Fig.1. Total final energy consumption of private households for living in Germany by area of application in 2010 and 2018 year-on-year comparison

Source: [12]

In addition, Germany has a large stock of around twelve million residential buildings that were built before 1977 when Thermal Insulation Ordinance came into force. These buildings afford around or even more than $150 \mathrm{kWh} / \mathrm{m} 2 \times$ a, depending on the type of construction and the state of renovation - i.e., they need around three to four times as much heating energy as a new building constructed in accordance with the energy saving ordinance (EnEV) requirements (such as a KfW Efficiency House 70: $\leq 45 \mathrm{kWh} / \mathrm{m}^{2} \times$ a). The high energy consumption of these old buildings is also reflected in the CO2 emissions (compare [13]).

While a poorly insulated residential building with 100 square meters that is heated with heating oil emits around $4 \mathrm{t} \mathrm{CO} 2 / \mathrm{a}$, a well-insulated building would only emit around $1.1 \mathrm{t}$ $\mathrm{CO} 2 / \mathrm{a}$. At the same time, the reduced amount of heating oil in well insulated buildings could reduce heating costs from around 1000 euros per year to around $450 € / a(0,67 € / 1$ heating oil).

Due to the poor insulation of many buildings, greenhouse gas emissions in the building sector have been high for years and had been falling only slightly. During the last years they had almost even stagnated (compare figure 2).

If by means of a better insulation of buildings these emissions mentioned in figure 2 could at least partially be reduced, additional synergetic effects of saving $\mathrm{CO} 2$ could be achieved, if the insulation material wouldn't be polystyrol or glass wool, but instead would be natural material made of renewable resources, like e.g., Typha (cattail). 


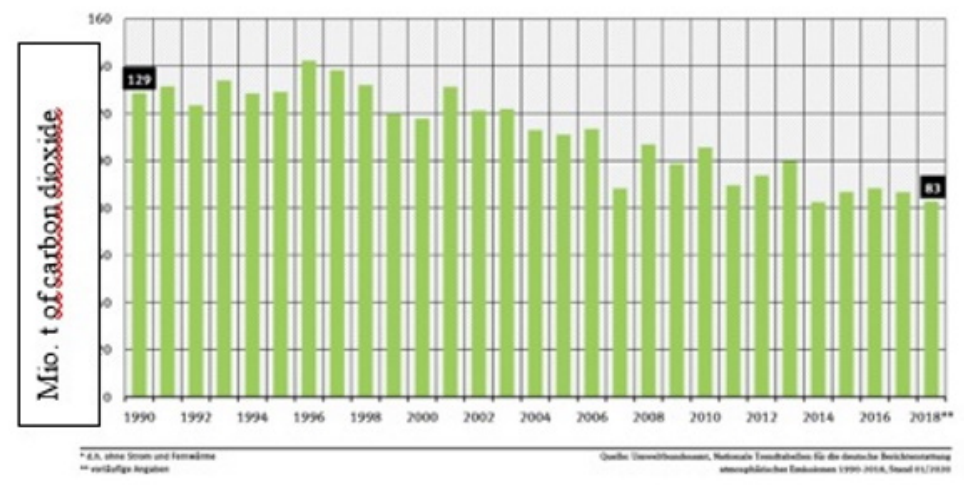

* Without electricity and distance heating

** provisional data

Fig. 2. Carbon dioxide emissions* from firing systems of private households in Germany. Source: [3]

The positive effects of paludiculture under wet conditions on a reduction in greenhouse gas emissions or even the reconstruction of a previously degraded bog has been confirmed many times in literature (compare e.g. [14-18]).

Significant reduction of GHG-emissions can be achieved if peatland restoration is done successfully: Up to $15 \mathrm{t} \mathrm{CO} 2 \mathrm{eq} /($ ha*a) in bogs and 30t CO2eq/(ha*a) in fens [19]).

The effect of growing Typha on an area measuring e.g., $32 \mathrm{~km}$ x $32 \mathrm{~km}$ - formerly used as degraded arable land - would capture 3 Mio. $t$ of carbon dioxide for a long time, if this Typha material would be processed to insulation material, helping to additionally save part of the 81 Mio. $\mathrm{t}$ of carbon dioxide emissions from heating devices in private households mentioned in figure 2 .

Growing Typha to avoid $\mathrm{CO} 2$ emissions (to a high degree) from agricultural land and to use Typha as insulation material to save fossil fuels for heating, could be a strategy to reduce CO2-emissions significantly.

But can this strategy be profitable?

\section{Calculation and Discussion}

Beginning from the year 2021, insufficient insulation and/or inefficient heating systems in buildings will reduce the incomes of those who live in these buildings much more than in the past.

How much does a ton of $\mathrm{CO} 2$ cost in Germany? The prices for carbon dioxide in the years 2021 until 2025 have already been fixed. In 2021 the CO2 tax is 25 euros (plus 19\% VAT) per tonne of carbon dioxide, with an annual increase of 5 euros (plus 19\% VAT) until 2025. From 2026 onwards, the emission certificates will be auctioned so that the price can be regulated by the market itself.

Thus, the price per ton of CO2 in the year 2025 will be 50 euros (plus VAT). In 2026: An auction will take place with a price range for $1 \mathrm{t}$ of $\mathrm{CO} 2$ between 55 and 65 euros plus VAT) from 2027: There will be auctions without a price range.

The price for a ton of carbon dioxide directly causes fossil fuels to get more expensive.

With an assumed living space of $120 \mathrm{~m} 2$ per household, in average 1500 liters of heating oil or 15,000 kilowatt hours of heating energy are required per year. That would correspond to about $4.7 \mathrm{t} \mathrm{CO} 2$ per year. This means that heating costs for such a house would increase by around 140 euros / year in 2021 compared to 2020 (apart from price changes for crude 
oil). In 2025, heating costs would be around 280 euros per year higher than in 2020 . This increase is politically intended and should provide an incentive for improving the insulation of buildings.

Insulation with the same heat transfer coefficient will help to reduce the amount of heating material in the same way.

Different insulation material may, however, cause different $\mathrm{CO} 2$ emissions during the production process, transportation to the customer, building them into houses and the dismantling in the future.

Glass wool is an often used "traditional" insulation material made from recycling material. Soft fiber boards made of wood are a competing product, made from plants.

The same saving effect upon heating material can be achieved with both materials. But the $\mathrm{CO} 2$ emissions during the production process differ. Therefore, it is not insignificant which insulation material an environmentally conscious user of a building actually buys. Therefore, we have a closer look upon both materials as an example.

$\mathrm{CO} 2$ emissions from the production of glass wool (a recycled product)

The greenhouse gas potential per kg of glass wool for the production processes (incl. raw material supply) is $0.845 \mathrm{~kg} \mathrm{CO} 2 \mathrm{eq} / \mathrm{kg}[20, \mathrm{p} .8]$. When installing the insulating felts in a house, additionally $0.0672 \mathrm{~kg}$ of CO2eq/ $\mathrm{kg}$ glass wool is required. In total (without taking into account the transport to the customer and the subsequent disposal at the end of the service life) all in all the atmosphere is polluted with around $912 \mathrm{~g} \mathrm{CO} 2 \mathrm{eq} / \mathrm{kg}$ glass wool used for insulating buildings.

In case of a functionally similar natural product (soft fiber board made of wood) from Pavatex [21, p. 7], for example, $1,179 \mathrm{~kg}$ of CO2eq $/ \mathrm{kg}$ soft fiber board even are removed from the atmosphere during the manufacturing process, including the growing of the raw material.

When installing the soft fiber boards, $0.0164 \mathrm{~kg}$ of $\mathrm{CO} 2 \mathrm{eq} / \mathrm{kg}$ are exhausted into the atmosphere. With using soft fiber boards made of wood, in total around 1,163 $\mathrm{kg}$ of $\mathrm{CO} 2 \mathrm{eq} / \mathrm{kg}$ of insulation material is removed from the atmosphere for a period of at least 50 years (without taking into account the transport to the customer and the subsequent disposal at the end of the service life).

This means that such natural products in comparison with glass wool do not only save heating material during the active use of a residential property, but the production of the insulation material itself relieves the atmosphere from CO2 (comp. table 1).

Table 1. Comparison of insulation materials: $\mathrm{CO} 2$-effects on the atmosphere.

\begin{tabular}{|c|c|c|}
\hline & $\begin{array}{l}\text { Insulation with glass wool } \\
\text { (recycled product) }\end{array}$ & $\begin{array}{l}\text { Insulation with soft fiber } \\
\text { boards made of wood } \\
\text { (natural product) }\end{array}$ \\
\hline Weight $/ \mathrm{m} 3$ & $25,02 \mathrm{~kg}$ & $140 \mathrm{~kg}$ \\
\hline $\begin{array}{l}\text { Weight of an insulation with a } \\
\text { thickness of } 15 \mathrm{~cm}\end{array}$ & $3,75 \mathrm{~kg} / \mathrm{m} 2$ & $21 \mathrm{~kg} / \mathrm{m} 2$ \\
\hline $\begin{array}{l}\text { Weight of the entire roof } \\
\text { insulation }(200 \mathrm{~m} 2) \text { weighs } \\
\text { around ... }\end{array}$ & $700 \mathrm{~kg}$ & $4200 \mathrm{~kg}$ \\
\hline $\begin{array}{l}\mathrm{CO}_{2 \mathrm{eq}} \text { along with the } \\
\text { insulation of the roof }\left(200 \mathrm{~m}^{2}\right)\end{array}$ & $\begin{array}{l}\text { Pollution of the atmosphere } \\
\text { with } \mathrm{CO}_{2} \text { for the material, } \\
\text { manufacturing and installation } \\
\text { in the property with around } \mathbf{6 4 0} \\
\text { kg } \mathbf{C O}_{2 \text { eq }} \\
\text { This is neglectable compared } \\
\text { to the possible saving of } \\
\text { heating oil per year. }\end{array}$ & $\begin{array}{l}\text { Long term fixation of } \mathrm{CO}_{2 \text { eq }} \text { : } \\
\text { around } 4900 \mathrm{~kg} \mathrm{CO} \mathrm{C}_{2 \text { eq with }} \\
\text { the roof's insulation in } \\
\text { addition to the possible } \\
\text { annually saving of heating oil. }\end{array}$ \\
\hline
\end{tabular}


In addition to saving fuel over the years (and the corresponding Output of CO2eq), the use of an insulation made of soft fiber board from wood compared to an insulation made of glass wool additionally directly and at once leads to a reduction in the $\mathrm{CO} 2$ pollution of the atmosphere of around $4 \mathrm{tCO} 2$.

However, there are also differences concerning the $\mathrm{CO} 2$-fixation of different natural building materials that are suitable for building insulation.

One hectare of forest (as a source for soft fiber boards) stores around 10-12 t CO2 / a on average for all age groups [22-23].

The surface growth of forest is around 10 solid cubic meters / ha and year (VFm / ha * a). With a specific weight of $450 \mathrm{~kg} / \mathrm{m} 3$ (spruce) and $720 \mathrm{~kg} / \mathrm{m} 3$ (beech) up to more than $1000 \mathrm{~kg} / \mathrm{m} 3$ for some tropical wood [24] means that the above-ground increase, and thus the $\mathrm{CO} 2$ that can really be bound in the long term through the material recycling of wood in Middle-Europe, is around 4,5 t to 7,2 $\mathrm{t}$ / ha and year. A significant part of the total $\mathrm{CO} 2$ bound by the forest is stored underground. When the wood is felled, the subterranean parts of the plant usually die off and release $\mathrm{CO} 2$ over time.

Can other renewable raw materials achieve better/more $\mathrm{CO} 2$ binding? And could this material also be used for construction/insulation for real estate refurbishment?

Depending on the nutrient supply and water supply, Typha can produce around $5 \mathrm{t}$ to 20 $\mathrm{t}$ (maybe even $25 \mathrm{t}$ ) of above-ground dry plant mass per year (in addition to the underground growth of the rhizomes). Typha can thus achieve a multiple of the long-term $\mathrm{CO} 2$ binding compared to a forest, if the rhizomes remain in the ground (and can sprout again in the next year) while the above-ground parts of the plants could be processed into building materials that are retained as building components for decades. The benefit for climate protection in the form of a long-term CO2 determination through the use of Typha materials can thus be increased each year up to five times compared to wooden materials.

So why Typha has almost not been used as a building material in Germany up to now?

- Inexpensive conventional insulation materials had been sufficiently available (mineral wool, glass wool, styrofoam, etc.). Natural insulation materials up to now often had been comparatively expensive. Anyone who wanted to use such natural materials for their property has switched to the building materials already available on the market (soft wood fiber boards, coconut mats, sheep's wool, cellulose flakes). Anyone who asked for Typha building materials could not find any.

- Thus it's a chicken-and-egg question: Because up to now there almost had been no demand for new building materials from Thypha, a supply (-chain) for these building materials has not been developed yet.

Would it still make sense to develop a new range of Typha building materials? Yes, but not based on planting Typha an agricultural land e.g. in Germany with high opportunity costs, but based on natural stocks of Typha (like in Bulgaria along the Mariza river) that have comparative cost advantages compared to e.g. Germany to set up a production chain for Typha boards.

Using Typha from natural stocks for producing insulation material also provides additional ecological advantages: Typha contributes to the purification of nutrient-rich, eutrophic bodies of water. If the harvested above-groung-material is used for producing insulation material, these nutrients won't be set free again in the water bodies. All in all, there are hardly any costs with growing Typha if the plants grow in suitable locations as wild stocks, as they do not have to be fertilized. The negative ecological effects of harvesting these wild stocks are minor if the harvest takes place in winter. Typha panels in comparison with soft fiber boards made of wood are of higher quality (resistance to mold, better load-bearing capacity). But the question of profitability still remains to be clarified.

How much can be earned solely by selling harvested Typha plants? 
For the harvested plant material (including the harvest costs) up to $0.3 € / \mathrm{kg}$ are paid by a German producer of Typha boards (costs for transportation have to be covered by the seller). The main costs associated with growing and harvesting Typha from natural stocks are the harvesting costs and maybe upheaval costs (thin out of the rhizomes) after 10 years or more. Tables 2 and 3 show the profit margin for two cases of revenue $(0,3 € / \mathrm{kg}$ vs. 0,2 $€ / \mathrm{kg})$

Table 2. Profit margin (for Bulgarian farmers) of Typha plants on natural stocks with a revenue of $0,30 € / \mathrm{kg}$ (the farmers cover the costs of transportation to Germany - compare table 3 )

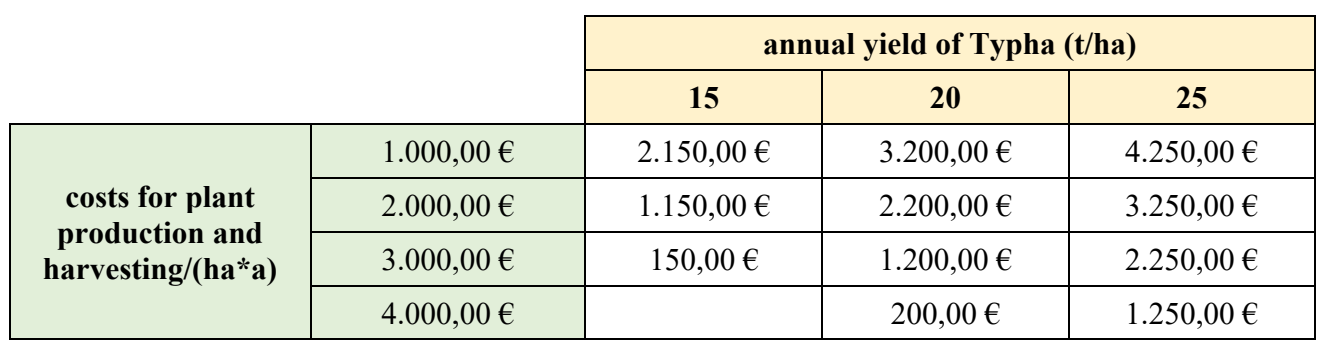

With the exception of high costs for plant production and harvesting, the profit margins of growing Typha are higher than the profit margins of average crop rotations.

Let us now assume the following situation (with prices and costs as they are relevant in Germany) (Table 3):

Table 3. Sample data to calculate the profitability of growing Typha and producing insulation material

\begin{tabular}{|c|c|}
\hline Area in Bulgaria to grow and harvest Typha in Bulgaria & 10 ha \\
\hline Possible costs for plant production and harvesting & $\begin{array}{c}\text { Vary from } 1.000 € / \text { ha up to } 3.000 \\
€ / \text { ha }\end{array}$ \\
\hline $\begin{array}{l}\text { Annuity of the investment for the machinery to produce } \\
\text { the Typha boards }\end{array}$ & $\begin{array}{c}55.000 €(2 \% \text { interest rate, maturity } \\
20 \text { years })\end{array}$ \\
\hline Operating costs for producing the Typha boards & $20.000 € / \mathrm{a}$ \\
\hline Price for magnesit to adhere the Typha plant parts & $0,2 € / \mathrm{kg}$ harvested Typha \\
\hline Insurance costs and royalties to be paid & $30.000 € / \mathrm{a}$ \\
\hline Personnel expenses (5 persons incl. administration) & $250.000 € / \mathrm{a}$ \\
\hline $\begin{array}{l}\text { Costs for transportation with } 40 \mathrm{t} \text { lorry (estimated by } \\
\text { using } \underline{\mathrm{htps}: / / \text { www.mein- }} \\
\frac{\text { onlinerechner.com/b2b/logistik/index-preview-824- }}{2 . \mathrm{html} \#)}\end{array}$ & $\begin{array}{l}3600 € \text { one distance from Bulgaria to } \\
\text { Germany }\end{array}$ \\
\hline $\begin{array}{c}\text { Amount of boards with } 1 \mathrm{~m}^{2}(16 \mathrm{~cm} \text { thick }) \text { that can be } \\
\text { produced with } 1 \mathrm{~m}^{3} \text { of Typha }\end{array}$ & 5 pieces \\
\hline
\end{tabular}

(annotation: If investors in Bulgaria are interested in producing Typha boards, the amount of the costs have to be adapted to the Bulgarian situation)

With the information in table 3 we can make a rough estimate about the profitability of establishing a Typha farm and run a production plant for Typha boards in Bulgaria, when these boards are to be sold in Germany (compare tables 4 and 5).

Table 4. Estimated profit (+) or loss (-) of producing Typha boards with $1.000 € /$ ha costs for producing and harvesting Typha.

\begin{tabular}{|l|c|c|c|c|}
\cline { 3 - 5 } \multicolumn{2}{c|}{} & \multicolumn{3}{c|}{ annual yield of Typha } \\
\cline { 3 - 5 } \multicolumn{2}{c|}{} & $\mathbf{1 5}(\mathbf{t} / \mathbf{h a})$ & $\mathbf{2 0}(\mathbf{t} / \mathbf{h a})$ & $\mathbf{2 5}(\mathbf{t} / \mathbf{h a})$ \\
\hline & 70 & $+39.070,52 €$ & $+173.570,52 €$ & $+308.070,52 €$ \\
\hline
\end{tabular}




\begin{tabular}{|c|c|c|c|c|}
\hline $\begin{array}{c}\text { revenue in } € / \mathbf{m}^{2} \\
\text { Typha board }(\mathbf{1 6} \\
\text { cm thick) }\end{array}$ & 60 & $-20.929,48 €$ & $+93.570,52 €$ & $+208.070,52 €$ \\
\cline { 2 - 5 } & 40 & $-80.929,48 €$ & $+13.570,52 €$ & $+108.070,52 €$ \\
\cline { 2 - 5 } & & $-140.929,48 €$ & $-66.429,48 €$ & $+8.070,52 €$ \\
\hline
\end{tabular}

Table 5. Estimated profit or loss of producing Typha boards with $3.000 € /$ ha costs for producing and harvesting Typha.

\begin{tabular}{|c|c|c|c|c|}
\cline { 3 - 5 } \multicolumn{2}{c|}{} & \multicolumn{3}{c|}{ annual yield of Typha } \\
\cline { 3 - 5 } \multicolumn{2}{c|}{} & $\mathbf{1 5}(\mathbf{t} / \mathbf{h a})$ & $\mathbf{1 5}(\mathbf{t} / \mathbf{h a})$ & $\mathbf{1 5}(\mathbf{t} / \mathbf{h a})$ \\
\hline \multirow{3}{*}{$\begin{array}{c}\text { revenue in } \mathbf{\epsilon} \mathbf{m} 2 \\
\text { Typha board }(16 \\
\text { cm thick) }\end{array}$} & 60 & $+19.070,52 €$ & $+153.570,52 €$ & $+288.070,52 €$ \\
\cline { 2 - 5 } & 50 & $-40.929,48 €$ & $+73.570,52 €$ & $+188.070,52 €$ \\
\cline { 2 - 5 } & 40 & $-100.929,48 €$ & $-6.429,48 €$ & $+88.070,52 €$ \\
\hline
\end{tabular}

On nutrient-rich locations with a high yield of Typha per hectare, comparatively high profits can be achieved (see yellow and especially blue colored table cells in Tables 4 and 5).

Not included in the calculation above are marketing costs. As in Germany there is a severe lack of building material made of wood that will presumably last for a longer time, there will be demand for any substitute for insulation.

\section{Conclusion, outlook, and proposal}

Climate change is an evidence. Therefore, there is a need to better insulate buildings in order to save heating material and - in many cases - the corresponding CO2 emissions. And there also is a need to better insulate buildings in order to be able to properly heat buildings solely with renewable energies.

There are various insulation materials that may help to improve insulation. Most promising, because the production of the material itself immobilizes $\mathrm{CO} 2$, are renewable resources.

Well known products are e.g., boards made of soft fiber wood. The support of wood as a building material, however, currently faces difficulties on the market. Additionally, there are materials with even better physical features, like e.g., boards made of Typha - with even a better rate of $\mathrm{CO} 2$-fixation than wood.

Pilot projects with the production of Typha meant for insulation e.g., took and currently take place in Bulgaria (compare Fraunhofer IMW [5] and Georgiev et al. [25]) where Typha is used locally in a DBU-project in Nessebar as insulation material.

As Typha plants grow in natural stocks in Bulgaria (Maritsa river), Romania (Danube delta) and other Middle and Eastern European countries producing Typha boards in these countries can be very profitable, as opportunity costs and high costs to establish the stocks do not have to be taken into consideration.

Besides improving the insulation of houses in Bulgaria, producing Typha to be exported to Germany or even to produce Typha boards for the export to Germany as a licensee of the company "Typha Technik Naturbaustoffe" might offer new strategic opportunities for farmers in Bulgaria.

\section{Summary}

Germany has formulated ambitious objectives to reduce the emission of climate-damaging gases. One important economic sector in Germany that still emits too much carbon dioxide 
is the building sector. Besides old heating systems, insufficient insulation is the problem in this sector.

By means of natural material (like Typha) used for insulation, not only the amount of $\mathrm{kWh}$ for heating might be reduced, but also a significant part of the carbon dioxide can be fixed for a long time, if insulation material is made of plants. Thus, contributing to a decrease (or a slowdown of the increase) of $\mathrm{CO} 2$ in the atmosphere

It is shown in this article, that natural stocks of Typha, where the plants are harvested in order to produce insulation material might offer farmers an additional income, if they export these plants to Germany.

Probably it might even be more profitable, if Typha from Bulgaria would be processed to Typha boards in Bulgaria and if these boards would be exported to Germany to substitute e.g., soft fiber boards, made of wood.

\section{References}

1. BMWi- Federal Ministry of Economics and Technology: Energy Concept, (2010), https://www.bmwi.de/Redaktion/DE/Downloads/E/energiekonzept2010.pdf? blob=publicationFile \&v $=5$

2. BMU - Climate Protection Plan 2050 - Climate Protection Policy Principles and Goals of the Federal Government, (2019), https://www.bmu.de/fileadmin/Daten_BMU/Download_PDF/Klimaschutz/klimaschutz plan 2050 bf.pdf

3. Umweltbundesamt, National trend table for the German reporting of atmospheric emissions 1990-2018, Stand 01/2020, (2020a)

4. KEA Climate Protection and Energy Agency Baden-Württemberg GmbH, Gray energy speaks for recyclable building materials - and for energetic renovation, (Editor 2021)

5. Fraunhofer IMW, Typha Bulgaria: Testing of an insulating material made from renewable raw materials for the renovation of apartment buildings with a small owner structure in Bulgaria, (2021), https://www.imw.fraunhofer.de/de/forschung/innovationsakzeptanz/projekte/referenzpr ojekte/Typha.html

6. Umweltbundesamt, Contribution of agriculture to greenhouse gas emissions, (2020b), https://www.umweltbundesamt.de/daten/land-forstwirtschaft/beitrag-derlandwirtschaft-zu-den-treibhausgas\#treibhausgas-emissionen-aus-der-landwirtschaft

7. UNFCCC: Land Use, Land-Use Change and Forestry; https://unfecc.int/topics/landuse/workstreams/land-use--land-use-change-and-forestry-lulucf

8. Bundesregierung: Peatland reduces carbon dioxide, (2021), https://www.bundesregierung.de/breg-de/aktuelles/moore-mindern-co2435992\#: :text=Allein\%20aus\%20entw\%C3\%A4sserten\%20deutschen\%20Mooren,de utschen $\% 20$ Landwirtschaft $\% 22 \% 2 \mathrm{C} \% 20$ so $\% 20$ Flasbarth

9. S. Abel, A. Barthelmes, G. Gaudig, N. Körner, J. Peters, Peatlands - the unknown climate protectors, Katapult (11), 36-44 (2018)

10. M. Krus, W. Theuerkorn, Th. Grosskinsky, Typha Cultivation in Agriculture, in Proceeding of 2nd International Conference - Water resources and wetlands, 11-13 September 2014, Tulcea, Romania (2014), http://www.limnology.ro/water2014/proceedings.html

11. B. Mahler, Living climate neutral, Vortrag Berliner Energietage (2019) 
12. Federal Statistical Office (Destatis), Energy consumption of private households for living, (2020), https://www.destatis.de/DE/Themen/Gesellschaft-

Umwelt/Umwelt/UGR/private-haushalte/Tabellen/energieverbrauchhaushalte.html;jsessionid=E2A0D5330D09B7F364A343DF75977D93.live732?view= main $\% 5$ bPrint $\% 5 \mathrm{~d}$

13. S. Hinterholzer, Minimize CO2 emissions in residential buildings, In: Die Wohnungswirtschaft, (2020), https://www.haufe.de/immobilien/zeitschrift/wohnungswirtschaft/diewohnungswirtschaft-ausgabe-42020-wohnungswirtschaft/co2-ausstossminderungspotenziale-im-wohngebaeudesektor-514148.html

14. M. Drösler, M. et al., Climate protection through moor protection in practice, Working reports from the Johann Heinrich von Thünen-Institut, (2010)

15. R. Schätzl, F. Schmitt, U. Wild, H. Hoffmann, Water protection and land use by Bulrush stocks, WasserWirtschaft, 11, 24-27 (2006)

16. W. Wichtmann, Chr. Schröder, H. Joosten, Paludiculture - productive use of wet peatlands, (Stuttgart, 2016)

17. W. Wichtmann, S. Wichmann, Paludiculture: appropriate management of rewetted moors, TELMA Beiheft, 4, 215 - 234, (2011)

18. U. Wild, T. Kamp, A. Lenz, S. Heinz, Ecol. Eng., 17(1), 49-54 (2001)

19. M. Drösler, What do moors have to do with the climate?, Laufener Spezialbeiträge., 2, 60-69 (2009)

20. Saint Gobain ISOVER AG Environmental Product Declaration. According to SN EN 15804 for uncovered glass wool, (2014),

https://www.isover.de/Dokumente/umweltproduktdeklaration-mineralwolledaemmstoff-im-niedrigen-

rohdichtebereich?destination=Dokumente/umweltproduktdeklaration-glaswolle, [Accessed: 19 February 2018]

21. Pavatex SA, Environmental product declaration according to ISO 14025 and EN 15804. Wood fiber insulation materials in the wet process $135-200 \mathrm{~kg} / \mathrm{m} 3,(2014)$, https://www.pavatex.com/fileadmin/pascal/EPD-PTXHolzfaserdaemmstoffe_im_Nassverfahren_135-200_kg.pdf, [Accessed: 19 February 2018]

22. Forest Enterprise Foundation, How much carbon dioxide (CO2) does the forest or a tree store, (2021), https://www.wald.de/waldwissen/wie-viel-kohlendioxid-co2speichert-der-wald-bzw-ein-baum/

23. LWF, Bayer, State Institute for Forests and Forestry, Carbon storage in trees, Leaflet 27 (2011)

24. Holz Kahrs, Gewicht von Holz, (2021), https://holz-kahrs.de/lexikon/gewicht-vonholz/\#: : :text=Gewicht $\% 20$ unserer\%20Holzarten.\%20Holzart. $\% 20$ Gewicht $\% 20$ in $\% 20$ kg\%2Fm\%C2\%B3.,Abachi.\%20400.\%20Angelim\%20Vermelho.\%201.000.\%20Bang kirai.\%201.000.

25. G. Georgiev et al., Examination of the transferability of a newly developed, innovative, sustainable building material for the thermal renovation of apartment buildings with a small owner structure in Bulgaria, Project report for the German Federal Environment Foundation, (2017) 